\title{
Protozoan parasite Perkinsus sp. infecting Crassostrea rhizophorae from the Coast of Rio Grande do Norte (Northeast of Brazil)
}

\begin{abstract}
The aquatic environment facilitates the horizontal transmission of pathogenic agents. The protozoa parasites of the genus Perkinsus cause an epidemic disease of marine bivalves throughout the world, often causing mortality in populations of molluscs. This study reports for the first time the presence of Perkinsus sp. infecting Crassostrea rhizophorae from the coast of the state Rio Grande do Norte. The samples of mangrove oysters (Crassostrea rhizophorae) occurred in summer, in December $(\mathrm{N}=10)$ of 2016, January $(\mathrm{N}=40)$ and February $(\mathrm{N}=40)$ of 2017 from the estuary Porto do Mangue. Two fragments of the gills were incubated in Ray's Fluid Thioglycollate Medium - RFTM. The ecological parameters parasitological were calculated. Were found parasitized five of the ninety oysters collected in porto do mangue estuary, which corresponded to a mean prevalence of perkinsose of $5.56 \%$. The intensity of infection by perkinsose ranged from very light the mild.
\end{abstract}

Keywords: Perkinsose, Mangroves, Mangrove oyster, RFTM
Volume 6 Issue 5 - 2017

\author{
Cl udio Giovanio da Silva,' Naibe Cristina de \\ Figueiredo, ${ }^{2}$ In s Xavier Martins, ${ }^{3}$ Jos Ticiano \\ Arruda Ximenes de Lima' \\ 'Laborat rio de Sanidade Aqu tica Centro de Ci ncias Agr rias \\ Universidade Federal Rural do Semi rido Brazil \\ 2Programa de Ps Gradua o em Produ o Animal Universidade \\ Federal Rural do Semi rido Brazil \\ ${ }^{3}$ Laborat rio de Moluscos Centro de Ci ncias Biol gicas e da Sa \\ de Universidade Federal Rural do Semi rido Brazil
}

Correspondence: $\mathrm{Cl}$ udio Giovanio da Silva Laborat rio de
Sanidade Aqu tica Centro de Ci ncias Agr rias Universidade Federal Rural do Semi rido Brazil, Email giovaniosı@bol.com.br

Received: November 12, 2017 | Published: November 27, 2017

\section{Introduction}

Brazil is the second largest country in extension of areas of mangroves, only lagging behind in Indonesia. ${ }^{1}$ The mangrove oysters, Crassostrea rhizophorae, is naturally found in estuarine environments tropical along the Brazilian coast, fixed on substrates, mainly in the roots of mangroves. ${ }^{2}$ The aquatic environment facilitates the horizontal transmission of pathogenic agents. ${ }^{3}$ In relation hostpathogen, the success or failure of the pathogen in the establishment of the infection in the host depends on the effectiveness of the system of internal defense of the host to eliminate the pathogen attacker or the ability of the pathogen to avoid host defense. ${ }^{4}$ The bivalve molluscs may be affected by many parasites that can cause diseases and contribute to reducing the populations naturally and mainly cultivated. ${ }^{5}$

The protozoa parasites of the genus Perkinsus cause an epidemic disease of marine bivalves throughout the world, often causing mortality in populations of molluscs. ${ }^{6,7}$ The events of mortality associated with this disease affect the dynamics of the population of oysters and the structure and ecological function of beds of oysters, strongly modulated by environmental conditions, the prevalence and intensity of infection increases with the temperature and salinity, and is marked by a transmission of generalized infection and fast. ${ }^{8}$ This disease is characterized today by high prevalence over large geographic regions. ${ }^{9}$

The genus Perkinsus is included in the group Perkinsidae, who is assigned to the Protalveolata, in the group of high ranking Alveolata, within the super group Sar. ${ }^{6}$ Since the emergence of this genus, seven species of Perkinsus are confirmed, were described as pathogens of marine snails in all over the world: ${ }^{10}$ Perkinsus marinus, ${ }_{11}$ Perkinsus olseni $(=$ P. Atlanticus $),{ }^{12}$ Perkinsus guqwadi, ${ }^{13}$ Perkinsus chesapeaki $\left(=\right.$ P. Andrewsi) ${ }^{14}$ Perkinsus mediterraneus,,${ }^{15}$ Perkinsus honshuensis ${ }^{16}$ and Perkinsus beihaiensis. ${ }^{17}$ Among these species, $P$. marinus and $P$. olseni require mandatory notifications to the World Organization for Animal Health, due to the risk that they represent for mollusk populations. ${ }^{18}$

In Brazil, four different species of Perkinsus have already been reported in molluscs: P. chesapeaki, P. Beihaiensis, $P$. Marinus and $P$. olseni, infecting three species of hosts: Crassostrea rhizophorae, Anomalocardia brasiliana \& Crassostrea gasar. ${ }^{19-21}$

The present paper reports for the first time the presence of Perkinsus sp. on the coast of the state of Rio Grande do Norte (Northeastern Brazil) infecting a host called mangrove oysters (Crassostrea rhizophorae).

\section{Materials and methods}

\section{Sampling area of animals}

Located in the northeast of Brazil, the coastal region of Rio Grande do Norte has humid tropical climate hot, with rains in the Summer (December to March) and dry conditions in Spring, Winter and Autumn (April to November) with an annual mean of $823 \mathrm{~mm}$ of rain and $32^{\circ} \mathrm{C}$ air temperature. The city of Porto do Mangue, where they were held the collections, comprises an area of approximately $332 \mathrm{~km}^{2}$ and Porto do mangue estuary is covered on both sides by the vegetation of mangrove.

The samples of mangrove oysters (Crassostrearhizophorae) occurred in summer, in December $(\mathrm{N}=10)$ of 2016, January $(\mathrm{N}=$ $40)$ and February $(\mathrm{N}=40)$ of 2017 from the Porto do Mangue estuary (05'04'04" S and 36 46'54" W) (Figure 1).

Manually, oysters were collected directly from the roots of the red mangrove (Rhizophora mangle) at low tide and were transported to the facilities of the laboratory alive in isothermal boxes. In the place of sampling, the data of temperature and salinity of the water were measured. 


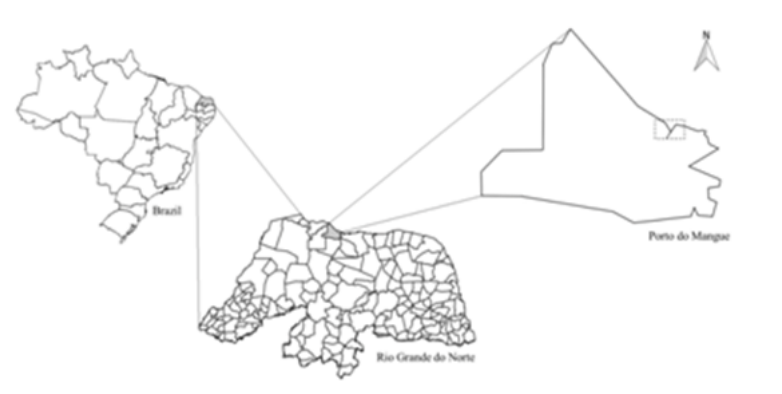

Figure I Map of Brazil showing the Rio Grande do Norte region and the sampling site Porto do Mangue (estuary).

The oysters passed through biometrics, where all measurements of shells were taken in millimeters $(\mathrm{mm})$ and subsequently kept in aquariums of $20 \mathrm{~L}$ (20 liters) in the closed system with sea water and aeration, where the oysters were kept for over $24 \mathrm{~h}$ before processing for the isolation of Perkinsus sp.

\section{Diagnosis of Perkinsus sp. by RFTM}

The oysters were opened and examined macroscopically and observed of pathological changes in the shell and body (mantle, gills, gonads and digestive gland). All animals collected in the estuary were processed in Ray's Fluid Thioglycollate Medium - RFTM. ${ }^{22}$

Two fragments of the gills were incubated in RFTM during 6 days in darkness at ambient temperature. After the incubation period, the samples were prepared for microscopic analysis by cutting the fragments and macerate the tissue on a slide and examining the preparations obtained by optical microscopy to verify the presence of parasites of the genus Perkinsus.

\section{Ecological parameters}

The ecological parameters parasitological, as the prevalence of pathogen (percentage of infected hosts, $\mathrm{P} \%$ ), mean intensity (average number of parasites per infected host, $\mathrm{mI}$ ) and mean abundance of infection (average number of parasites per host, $\mathrm{mA}$ ) were calculated according to Bush et al. ${ }^{23}$

The scale of intensity of infection with Perkinsus sp. in the tissues of the mangrove oysters (C. rhizophorae) was obtained in accordance with Sabry et al. ${ }^{24}$ without infection = without cells observed in the whole preparation; infection very mild $=$ up to 10 cells observed in the whole preparation; infection mild $=11$ to 100 cells observed in the whole preparation; infection moderate $=$ at least 40 cells observed in each of the 10 fields of the microscope (40x) scattered about the fabric; and heavy infection = more than 40 cells observed in each of the 10 fields of the microscope (40x) scattered over the fabric.

\section{Results}

The average height $( \pm \mathrm{SD})$ of oysters collected in the Porto do mangue estuary was $46.8 \pm 4.4 \mathrm{~mm}$. The temperature and the salinity of the water observed at the time of collection were $30^{\circ} \mathrm{C}$ and $37 \%$ respectively. In relation to pathological changes in the shells and body of oysters, no alterations were observed atypical of this species.

Were found parasitized five (n5) of the ninety (n90) oysters collected in Porto do Mangue estuary in December/2016, January and February 2017, which corresponded to a mean prevalence of perkinsose of $5.56 \%$. The intensity of infection by perkinsose ranged from very light $(n=3)$ the mild $(n=2)$ in the months in study. December was the month that there was value of prevalence and mean intensity of infection recorded (Table 1), this due this month have had a number of individuals collected.

Table I Monthly Indexes of infection prevalence (P\%) by perkinsosis and average shell length (mean \pm SD of C.rhizophorae)

\begin{tabular}{llll}
\hline Month & N & P\% & Shell Length $(\mathbf{m m})$ \\
\hline December & 10 & 0.00 & $44.2 \pm 3.5$ \\
January & 40 & 7.50 & $47.4 \pm 5.9$ \\
February & 40 & 5.00 & $47.5 \pm 3.0$ \\
\hline
\end{tabular}

The examination with an optical microscope parts after branchial process in RFTM, it was identified that the protozoan Perkinsus sp., belonging to the class Perkinsea, family Perkinsidae and genus Perkinsus ${ }^{25}$ The cells of the parasite were spherical and stained with black, with a diameter of $28.23 \mu \mathrm{m}$ to $47.12 \mu \mathrm{m}$, a typical characteristic of this species (Figure 2).

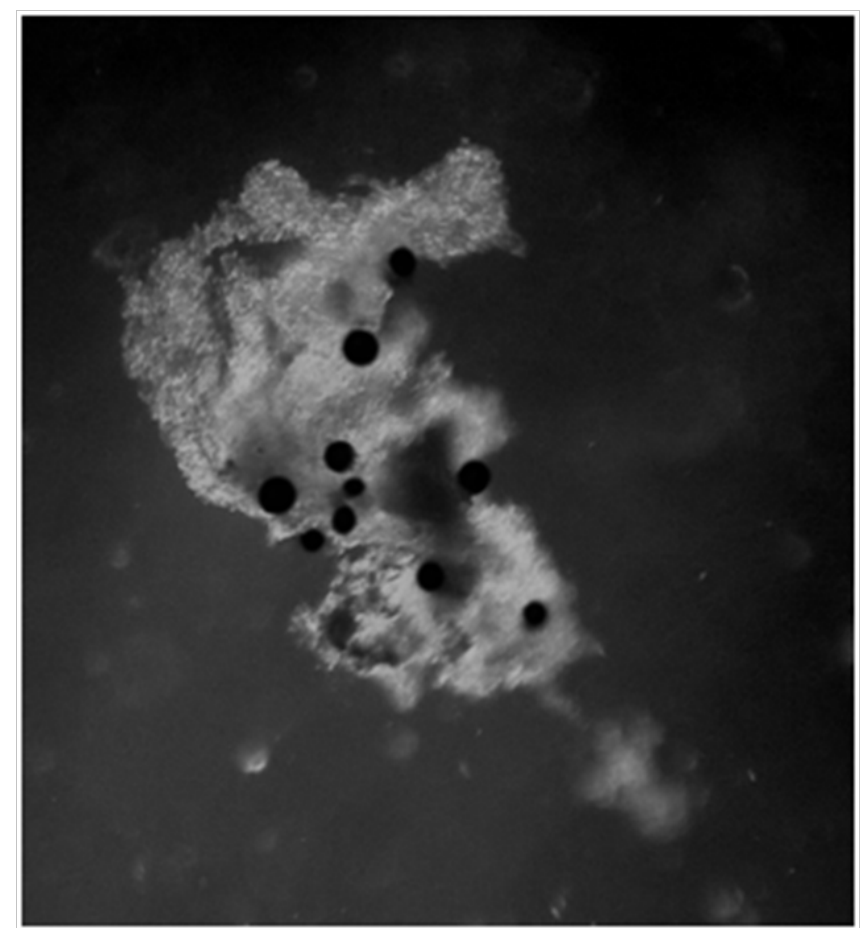

Figure 2 Cells of Perkinsus sp. infecting the tissue of the mangrove oysters (C. rhizophorae).

\section{Discussion}

This is the first report of the occurrence of Perkinsus sp. parasitizing mangrove oysters (Crassostrearhizophorae) in Rio Grande do Norte (Northeastern Brazil). The preparation in RFTM revealed the presence of pathogenic cells of Perkinsus sp. infecting the tissues of $C$. rhizophorae. The prevalence and mean intensity of infection in this study were higher than those found by Neto et al. ${ }^{18}$ where he obtained a prevalence in $P$. chesapeaki $(2.6 \%)$ and $P$. beihaiensis (3.3\%) infesting C. rhizophorae estuary of the Jaguaribe River (Ceará state), which forms the border with Rio Grande do Norte.

The prevalence of infection by perkinsose were considerably lower than those found in studies with molluses from other regions of Brazil, such as those found by Sabry et al..$^{24,26}$ (5.78 and 23.33\%) in the estuary of Pacoti with C. rhizophorae on the coast of Ceará. 
In $C$. rhizophorae on the coast of Bahia, the mean prevalence of Perkinsus sp. has reached $63 \%{ }^{27}$ Queiroga et al. ${ }^{21,28}$ has recorded an mean prevalence of 93.3 and $48.9 \%$ respectively in C. gasar at the estuary of the Mamanguape River (Paraíba state). Silva et al. ${ }^{19}$ reported a prevalence of $100 \%$ in $P$. marinus infecting $C$. rhizophorae in Paraíba River (Paraíba state). Ferreira et al. ${ }^{20}$ in the estuary of the river Timonha (Ceará state) obtained a prevalence of 14.7\% of Perkinsus sp. infest Anomalocardia brasiliana.

In other regions, the infection prevalences estimated by the RFTM assays by Reece et al. ${ }^{30}$ ranged from 3 to $100 \%$ in Crassostrea virginica Chesapeake Bay, USA. Enríquez-Espinoza et al. ${ }^{31}$ in Gulf of California estimated prevalence of $100 \%$ in Crassostrea gigas through RTFM assays. The estimated prevalence by Cáceres-Martínez et al. ${ }^{32}$ varied from 1 to $6 \%$ in Crassostrea corteziensis on the Pacific coast of Mexico. Park et al. ${ }^{33}$ studying Protothacajedoensis noted prevalence ranged from 37.0 to $53.9 \%$ in Korean waters. Park et al. ${ }^{34}$ in the coast of Japan reported prevalence varying of $20.2-96.7 \%$ in Ruditapes philippinarum.

Results from the present study suggest that the site of collection it's more of an area of the northeastern region of Brazil with the presence of these pathogenic parasites, but the values of the monthly prevalence were below $8 \%$, therefore, the infection may be likely to be a transitional event. ${ }^{19}$ Will still be needed analysis with the molecular biology to confirm phylogenetic and have a molecular diagnosis to identify species of Perkinsus in molluscs from Rio Grande do Norte. According to Reece et al. ${ }^{30}$ the infection prevalences estimated by RFTM and molecular assays are generally comparable, but in some species there may be differences.

Differences in prevalence between months could be affected by biological and environmental conditions. Future studies must consider these aspects as well as employ RFTM method for detection of this parasite in the region. The results of this study open the door for carrying out taxonomic, pathogenic and epidemiological studies on perkinsiosis in Rio Grande do Norte.

According to Silva et al., ${ }^{29}$ the dynamics of infection by $P$. marinus and $P$. olseni in C. gasar $(=C$. brasiliana) may have seasonal variations in tropical climate and be associated with cultural practices. This variation of infection may also be associated with C. rhizophorae, which would explain the low prevalence in the study. Mollusc species have different responses to a pathogenic protozoan infection, and environmental factors such as temperature and salinity are involved in the infective process. ${ }^{31,35}$ Perkinsosis is an illness associated with warm waters which is a characteristic of the northeastern region of Brazil.

Second da Sabry et al. ${ }^{26}$ the effects of perkinsosis on the host and the natural populations of oysters from the northeast region should be evaluated. It is imperative that they be introduced strategies to restrict the spread of the disease.

According to Ferreira et al. ${ }^{20}$ due to the large differences observed in the prevalence of Perkinsus sp. in molluscs of the entire Brazilian coast, further studies are needed to better understand the dynamics of this parasitic pathogen in these species. In conclusion, this is the first study that identifies, Perkinsus sp. naturally infecting the mangrove oysters (C. rhizophorae) in the state of Rio Grande do Norte (Northeastern Brazil).

\section{Ethical approval}

All procedures performed this study involving animals were in accordance with the ethical standards of the institution.

\section{Acknowledgements}

Thank CNPq (Conselho Nacional de DesenvolvimentoCientífico e Tecnológico) and CAPES (Coordenação de Aperfeiçoamento de Pessoal de Nível Superior) by research grants and financial support given to post-graduate programs and undergraduate, the UFERSA for technical and scientific support. In addition, a special thanks to Professor Marcia Avelino Coelho by the audit provided to the study.

\section{Conflicts of interest}

None.

\section{References}

1. Filho PWMS. Costa de Manguezais de Macromare da Amazonia: Cenarios Morfologicos, Mapeamento e Quantificacao de Areas Usando Dados de Sensores Remotos. Rev Bras Geofisica. 2005;23(4):427-435.

2. Guimarães IM, Antonio ÍG, Peixoto S, et al. Salinity influence on the survival of mangrove oyster, Crassostrea rhizophorae. Arq Ciências do Mar. 2008;41:118-122.

3. Thatcher VE. Os crustáceos parasitos de peixes da Amazônia Brasileira. II - Ergasilus leporinidis n. sp. (Copepoda: Cyclopoidea) das branquias de Leporinus fasciatus (Bloch). Acta Amaz. 198111(4):723-727.

4. Chu FE, Peyre JF La. Perkinsus marinus susceptibility and defenserelated activities in eastern oysters Crassostrea virginica: temperature effects. Dis Aquat Organ. 1993;16:223-234.

5. Sabry RC, Magalhães ARM. Parasitas em ostras de cultivo (Crassostrea rhizophorae e Crassostrea gigas) da Ponta do Sambaqui, Florianópolis, SC. Arq Bras Med Vet Zootec. 2005;57:194-203.

6. Ramilo A, Carrasco N, Reece KS, et al. Update of information on perkinsosis in NW Mediterranean coast: Identification of Perkinsus spp. (Protista) in new locations and hosts. J Invertebr Pathol. 2015;125:3741.

7. Elandaloussi LM, Carrasco N, Roque A, et al. First record of Perkinsus olseni, a protozoan parasite infecting the commercial clam Ruditapes decussatus in Spanish Mediterranean waters. J Invertebr Pathol. 2009; 100(1):50-53.

8. Powell EN, Hofmann EE. Models of marine molluscan diseases: trends and challenges. J Invertebr Pathol. 2015;131:212-225.

9. Powell EN. What is going on with Perkinsus marinus in the Gulf of Mexico? Estuaries and Coasts. 201740(1):105.

10. Ramilo A, Pintado J, Villalba A, et al. Perkinsus olseni and P. chesapeaki detected in a survey of perkinsosis of various clam species in Galicia (NW Spain) using PCR-DGGE as a screening tool. J Invertebr Pathol. 2016;133:50-58.

11. Mackin JG, Owen MM, Collier A. Preliminary note on the occurrence of a new protozoan parasite, Dermocystidium marinum n. sp., in Crassostrea virginica (Gmelin). Science (80- ). 1950111:328-329.

12. Lester RJG, Davis GHG. A new Perkinsus species (Apicomplexa, Perkinsea) from the abalone Haliotis ruber. $J$ Invertebr Pathol. 1981;37(2):181-187.

13. Blackbourn J, Bowe SM, Meyer GR. Perkinsus qugwadi sp. nov. (incertae sedis), a pathogenic protozoan parasite of Japanese scallops, Patinopecten yessoensis, cultured in British Columbia, Canada. Can J Zool. 1998;76(5):942-953.

14. McLaughlin SM, Tall BD, Shaheen A, et al. Zoosporulation of a new Perkinsus species isolated from the gills of the softshell clam Mya arenaria. Parasite. 2000;7(2):115-122.

15. Casas SM, Grau A, Reece KS, et al. Perkinsus mediterraneus n. sp., a protistan parasite of the European flat oyster Ostrea edulis from the Balearic Islands, Mediterranean sea. Dis Aquat Organ. 2004;58(23):231-244. 
16. Dungan CF, Reece KS. In vitro propagation of two Perkinsus spp. parasites from Japanese Manila clams, Venerupis philippinarum, and description of Perkinsus honshuensis n. sp. J Eukaryot Microbiol. 2006;53(5):316-326.

17. Moss JA, Xiao J, Dungan CF, et al. Description of Perkinsus beihaiensis n. sp., a new Perkinsus sp. Parasite in Oysters of China. $J$ Eukaryot Microbiol. 2008;55(2):117-1130.

18. Neto MPD, Gesteira TCV, Sabry RC, et al. First record of Perkinsus chesapeaki infecting Crassostrea rhizophorae in South America. J Invertebr Pathol. 2016;141:53-6.

19. Silva PM da, Vianna RT, Guertler C, et al. Fernández-Boo S, et al. First report of the protozoan parasite Perkinsus marinus in South America, infecting mangrove oysters Crassostrea rhizophorae from the Paraíba River (NE, Brazil). J Invertebr Pathol. 2013;113(1):96-103.

20. Ferreira LP, Sabry RC, Silva PM da, et al. First report of Perkinsus beihaiensis in wild clams Anomalocardia brasiliana (Bivalvia: Veneridae) in Brazil. Exp Parasitol. 2015;150:6770

21. Queiroga FR, Vianna RT, Vieira CB, et al. Parasites infecting the cultured oyster Crassostrea gasar (Adanson, 1757) in Northeast Brazil. Parasitology. 2015;142(6):756-766.

22. Ray SM. A review of the culture method of detecting Dermocystidium marinum with suggested modifications and precautions. Proc Natl Shellfish Assoc. 1966;54:55-69.

23. Bush AO, Lafferty KD, Lotz JM, et al. Parasitology Meets Ecology on it own Terms: Margolis et al. Revised. J Parasitol. 1997;83(4):575-583.

24. Sabry RC, Rosa RD, Magalhães ARM, et al. First report of Perkinsus sp. infecting mangrove oysters Crassostrea rhizophorae from the Brazilian coast. Dis Aquat Organ. 2009;88(1):13-23.

25. Levine ND. Perkinsus gen. $n$. and other new taxa in the protozoan phylum Apicomplexa. J Parasitol. 1978;64: 549.

26. Sabry RC, Gesteira TCV, Magalhães ARM, et al. Parasitological survey of mangrove oyster, Crassostrea rhizophorae, in the Pacoti River Estuary, Ceará State, Brazil. J Invertebr Pathol. 2013;112(1):24-32.
27. Brandão RP, Boehs G, Sabry RC, et al. Perkinsus sp. infecting oyster Crassostrea rhizophorae (Guilding, 1828) on the coast of Bahia, Brazil. J Invertebr Pathol. 2013;112(2):138-141.

28. Queiroga FR, Marques-santos LF, Hégaret H, et al. Immunological responses of the mangrove oysters Crassostrea gasar naturally infected by Perkinsus sp. in the Mamanguape Estuary, Paraíba state. Fish Shellfish Immunol. 2013;35(2):319-327.

29. Silva PM da, Scardua MP, Vianna RT, et al. Two Perkinsus spp. infect Crassostrea gasar oysters from cultured and wild populations of the Rio São Francisco estuary, Sergipe, northeastern Brazil. J Invertebr Pathol. 2014119:62-71.

30. Reece KS, Dungan CF, Burreson EM. Molecular epizootiology of Perkinsus marinus and P.chesapeaki infections among wild oysters and clams in Chesapeake Bay, USA. Dis Aquat Organ. 2008;82(3):237248

31. Enríquez-Espinoza TL, Grijalva-Chon JM, Castro-Longoria R, et al. Perkinsus marinus in Crassostrea gigas in the Gulf of California. Dis Aquat Organ. 2010;89(3):269-273.

32. Cáceres-Martínez J, Vásquez-Yeomans R, Padilla-Lardizábal G, et al. Perkinsus marinus in pleasure oyster Crassostrea corteziensis from Nayarit, Pacific coast of México. J Invertebr Pathol. 2008;99(1):66-73.

33. Park K Il, Ngo TTT, Choi SD, et al. Occurrence of Perkinsus olseni in the Venus clam Protothacajedoensis in Korean waters. J Invertebr Pathol. 2006;93(2):81-87.

34. Park K Il, Tsutsumi H, Hong JS, et al. Pathology survey of the shortneck clam Ruditapes philippinarum occurring on sandy tidal flats along the coast of Ariake Bay, Kyushu, Japan. J Invertebr Pathol. 2008;99(2):212-219.

35. La Peyre M, Casas S, La Peyre J. Salinity effects on viability, metabolic activity and proliferation of three Perkinsus species. Dis Aquat Organ. 2006;71(1):59-74. 